\title{
PELATIHAN DAN PENYULUHAN PEMBIBITAN TANAMAN BUAH DI DESA SEI ROTAN KECAMATAN PERCUT SEI TUAN KABUPATEN DELI SERDANG
}

\author{
Erlita Chaniago ${ }^{1}$. Aisyah Lubis ${ }^{2}$, Nurma $\mathrm{Ani}^{3}$, Farida Hariani ${ }^{4}$ \\ 1,2,3,4 Jurusan Agroteknologi, Fakultas Pertanian Universitas Al Azhar J1 Pintu Air IV \\ No. 214 Kwala Bekala Padang Bulan Medan, 20142 \\ *erlitaaidil@gmail.com
}

\begin{abstract}
ABSTRAK. Salah satu perbanyakan tanaman yang paling mudah dilakukan secara massal dan biayanya murah adalah perbanyakan melalui biji atau perbanyakan secara generatif (seksual). Dalam perbanyakan secara generatif, biji digunakan sebagai alat perbanyakan. Perbanyakan tanaman secara generatif memiliki kelebihan dan kekurangan. Kelebihan perbanyakan tanaman secara generatif adalah tanaman baru bisa diperoleh dengan mudah dan cepat, biaya yang dikeluarkan relatif murah, umur tanaman lebih lama, tanaman yang dihasilkan memiliki perakaran yang lebih kuat. Sedangkan kelemahan perbanyakan secara generatif adalah tanaman baru yang dihasilkan belum tentu memiliki sifat yang sama dengan tanaman induknya, varietas baru yang muncul belum tentu lebih baik, waktu berbuah lebih lama dan kualitas tanaman baru diketahui setelah tanaman berbuah. Tujuan dari pengabdian masyarakat ini adalah memberikan penyuluhan dan pelatihan kepada masyarakat tentang teknik pembibitan tanaman buah. Metode yang diberikan adalah dengan cara diskusi dan bermusyawarah bagaimana cara atau teknik pembibitan tanaman buah dan selanjutnya dilakukan pelatihan pembibitan. Setelah itu kita tetap melakukan evaluasi dan monitoring kegiatan. Hasil yang diperoleh masyarakat sudah mengetahui dan memahami hal-hal yang harus disiapkan dalam pembibitan mulai dari penyiapan media tanam , pembuatan naungan, perkecambahan sampai pemindahan bibit di polybag. Dan kesimpulannya masyarakat paham teknik pembibitan tanaman.
\end{abstract}

Kata kunci: perbanyakan tanaman, benih, pembibitan

\begin{abstract}
One of the most straightforward plant propagation in bulk and cheap is propagation through seeds or generative (sexual) propagation. In generative propagation, seeds are used as a means of propagation. Sexual propagation of plants has advantages and disadvantages. The benefits of generative plant propagation are that new plants can be obtained easily and quickly, the costs incurred are relatively cheap, the age of the plant is longer, the resulting plant has more robust roots. While the weakness of generative propagation is that the new plants produced do not necessarily have the same properties as the parent plant, the new varieties that appear are not necessarily better. The fruiting time is longer, and the plants' quality is only known after the plants bear fruit. This community service aims to provide counseling and training to the community about fruit plant seedling techniques. The method given is by discussion and deliberation on the process or practice of seeding fruit plants and then conducting nursery training. After that, we continue to evaluate and monitor activities. The results obtained by the community already know and understand the things that must be prepared in the nursery, starting from preparing planting media, making shade, germination, to transferring seeds in polybags. And the conclusion is that the community understands plant nursery techniques.
\end{abstract}

Keywords: plant propagation, seeds, nursery

\section{PENDAHULUAN}

Tanaman buah adalah tanaman yang menghasilkan buah yang dimakan (komsumsi) dalam keadaan segar, baik sebagai buah meja atau bahan terolah dan secara umum tidak tahan disimpan lama. Sifat produk tanaman buah adalah: (1) Mudah rusak (perishable), sehingga diperlukan suatu teknologi untuk mempertahankan mutu buah; (2) Risiko besar. Buah dengan sifat mudah rusak akan $\mathbf{1 0} \mid \mathrm{P}$ a g e berpengaruh terhadap ketersediaan dan permintaan pasar, sehingga fluktuasi harga tinggi. Misalnya perubahan cuaca, adanya serangan hama atau penyakit tertentu akan mempengaruhi produksi baik kuantitas maupun kualitas; (3) Musiman. Tanaman buah umumnya tanaman berumur panjang (prennial), sehingga berbuah adalah musiman yang berakibat tidak tersedia setiap saat. Pada musim 
berbuah umumnya produk melimpah, sehingga diperlukan suatu teknologi untuk dapat menampung produk tersebut ; (4) Bulky. Buah umumnya mempunyai kandungan air tinggi, sehingga memerlukan ruang besar atau perlakuan khusus di dalam transportasi maupun di penyimpanan. Hal tersebut akan menyebabkan biaya tinggi; dan (5) Spesialisasi geografi. Tanaman buah membutuhkan agroklimat tertentu untuk menghasilkan buah dengan kuantitas dan kualitas tertentu, misalnya salak bali, jeruk siam madu karo, duku Palembang, rambutan binjai, dan sebagainya (I Wayan Wiraatmaja,2017).

Perbanyakan dengan biji juga dikenal sebagai pembibitan generatif atau seksual karena menggunakan biji atau bagian tanaman yang sudah dibuahi. Biji berasal dari hasil penyerbukan antara putik dengan benang sari.

Kelemahan bibit generatif dalam pembibitan ini antara lain tanaman lebih lama menghasilkan buah, serta kualitas buah baru diketahui ketika tanaman berbuah.

Kelebihan menggunakan biji sebagai cara perbanyakan yang pertama adalah pembibitan dapat dilakukan dengan mudah dan murah. Ada kemungkinan menghasilkan varietas baru yang lebih baik.

Tanaman juga akan tumbuh dengan sehat, kekar, kuat, dan berumur panjang. Terakhir, kalau kebetulan biji bersifat poliembrional, sifat-sifat tanaman baru bisa pula sama persis dengan induknya. Jika demikian, sifat positif dari induknya pun tetap dapat diwariskan. (Distan, 2019)

Perbanyakan tanaman dengan biji (generatif) terutama dilakukan untuk penyediaan batang bawah yang nantinya akan diokulasi atau disambung dengan batang atas dari jenis unggul. Perbanyakan dengan biji juga masih dilakukan terutama pada tanaman tertentu yang bila diperbanyak dengan cara vegetatif menjadi tidak efisien (tanaman buah tak berkayu).

a. Pemilihan biji untuk bahan perbanyakan - Kesulitan dari pengumpulan ini adalah susah mendapatkan biji yang seragam varietasnya.

Memisahkan biji dari daging buahnya dan dicuci sampai bersih.

Biji kemudian dimasukkan ke dalam air. Hanya biji yang tenggelam yang ditanam untuk bibit, sedangkan yang hampa dibuang. Biji buah yang mempunyai kulit pembungkus keras seperti pada biji mangga, kulit pembungkus ini harus

11|P a g e disayat dan dibuang untuk memudahkan pertumbuhan akar.

b. Menyemaikan biji dalam bedeng persemaian

Biji buah yang besar seperti mangga, durian, alpukat, nangka, dan lain-lain, sebaiknya disemaikan dalam bedengan di lapang. Bedengan disiapkan dengan menggemburkan tanah

-Setelah bedengan persemaian siap, maka selanjutnya adalah menyemaikan biji dalam bedengan dengan arah memotong bedengan (lebar bedengan) kemudian ditutup kembali dengan media di sekitar larikan.

Waktu menanam biji harus diperhatikan agar peletakan bijinya jangan terbalik. Untuk mangga bagian perutnya (bagian biji yang melengkung) menghadap ke bawah, sedangkan untuk durian, alpukat, kemang dan nangka bagian sisi dimana embrio (bakal tunas dan akar) berada di bagian bawah. Bila letaknya terbalik, maka pertumbuhan akar dan batangnya akan membengkok dan akan mengganggu pertumbuhan bibit selanjutnya.

Untuk menghindarkan derasnya air hujan dan teriknya sinar matahari, bedengan diberi naungan

Biji yang disemaikan biasanya mulai berkecambah (tunas muncul di atas permukaan tanah) antara 1-3 minggu setelah penyemaian, tergantung jenis tanamannya. (Nugroho $\mathrm{H}$. Prastowo,dkk. 2006).

2. Persemaian kedua

a. Persemaian kedua dilakukan pada polibag yang diisi media campuran pupuk kandang, sekam padi dan tanah dengan perbandingan 1:1:1. Polibag berisi media disusun 5 barisan memanjang.

b. Memindahkan bibit ke persemaian kedua Sebelum bibit dipindahkan ke persemaian kedua atau di polibag, susun polibag yang sudah terisi media secara berderet 5 buah memanjang untuk memudahkan perawatan. Buatlah naungan. Siramlah polibag yang sudah dipersiapkan dengan air secukupnya. Ketika mencabut bibit, diusahakan biji jangan sampai lepas, pilihlah semai yang sudah berdaun 2- 4 helai.

Tanamlah semai satu persatu ke dalam polibag dan usahakan agar tertanam dengan tegak lurus. Siramlah 2 hari sekali. Lakukan pemberantasan hama dan penyakit bila diperlukan. Untuk merangsang pertumbuhan bisa diberi pupuk 
daun misalnya Gandasil D. Setelah 2 -3 bulan dipersemaian, bibit sudah siap untuk penyambungan maupun okulasi (Pratiknyo Purnomosidhi, dkk, 2007)

Pada bulan Juni tahun 2021, pelaksanaan kegiatan pengabdian kepada masyarakat bertempat di desa Sei Rotan kec. Percut Sei Tuan kab. Deli Serdang. Berdasarkan hasil pengamatan lapangan menunjukkan bahwa tingginya keinginan dari sebagian besar masyarakat untuk dapat melakukan pembibitan tanaman yang berasal dari biji agar dapat meningkatkan perekonomian mereka.

Berdasarkan permasalahan di atas, Salah satu program yang dilaksanakan adalah sosialisasi cara pembibitan tanaman yang berasal dari biji. Program ini memiliki tujuan bagaimana memanfaatkan buah-buahan yang sudah tidak dapat diperjual belikan dan tidak layak dikonsumsi agar dapat dimanfaatkan sebagai sumber bahan baku untuk pembibitan tanaman buah dan berdampak baik bagi lingkungan

\section{METODE}

Berdasarkan permasalahan yang dihadapi dalam hubungannya dengan program yang akan dilakukan untuk menyelesaikan permasalahan tersebut, maka metode pendekatan yang dilakukan antara lain:

1. Diskusi kelompok dan pelatihan pembibitan tanaman buah yang berasal dari biji.

Kegiatan ini dilakukan dengan mendengarkan pendapat dan pandangan masyarakat tentang permasalahan yang terjadi dan bagaimana permasalahan tersebut dapat diatasi melalui diskusi sehingga tercipta kebersamaan dan gotong royong dari masyarakat.

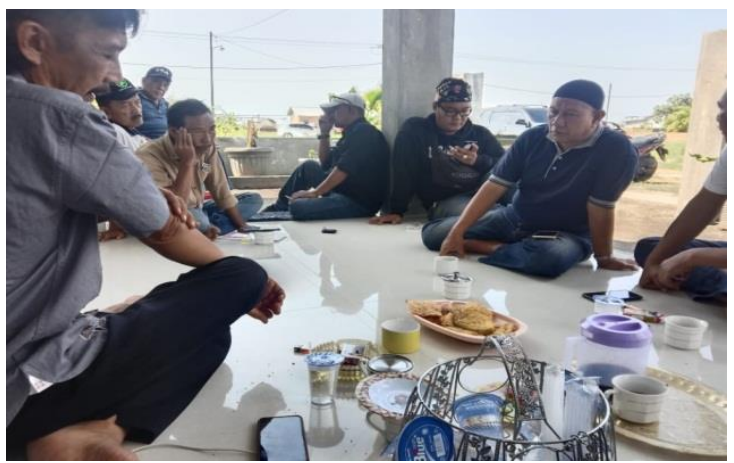

Gambar 1. Diskusi dan Musyawarah

Setelah melakukan diskusi dan didapat kata mufakat, maka kegiatan dilanjutkan dengan memberikan pelatihan kepada masyarakat $\mathbf{1 2} \mid \mathrm{P}$ a g e bagaimana teknik pembibitan tanaman yang berasal dari biji. Pelatihan dimulai dari penyiapan media tanam, pembuatan naungan untuk perkecambahan dan pembibitan, perkecambahan biji, pengisian polybag, pemindahan bibit ke polybag, penyusunan polybag di naungan pembibitan sampai ke pemeliharaan bibit.

2. Monitoring dan evaluasi

Setelah seluruh kegiatan dilaksanakan maka dilaksanakan monitoring terhadap kegiatan untuk selanjutnya dilakukan evaluasi yang menjadi dasar untuk perbaikan selanjutnya

\section{HASIL YANG DICAPAI}

Sesuai dengan metode pelaksanaan kegiatan pengabdian kepada masyarakat telah dilakukan kegiatan ceramah dan diskusi serta pelatihan pembibitan tanaman buah yang berasal dari biji.

Kegiatan yang dilakukan adalah :

\section{Penyiapan Media Tanam}

Kegiatan pertama yang dilakukan adalah menyiapkan tanah, arang sekam dan pupuk kandang. Ke tiga media tanam ini akan dicampur menjadi satu dengan perbandingan 1:1:1. Hasil yang dicapai petani dapat memahami media yang baik untuk pertumbuhan bibit tanaman dan tersedianya hara bagi tanaman tersebut

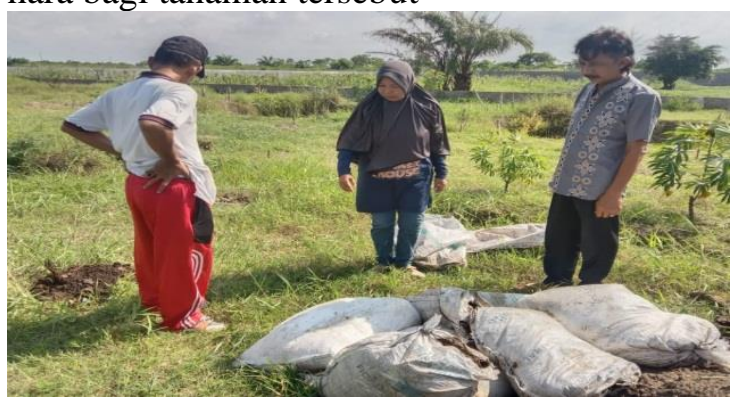

Gambar 2. Media tanam terdiri dari tanah, pupuk kandang dan arang sekam

\section{Pembuatan Naungan untuk Perkecambahan} dan Pembibitan

Kegiatan yang ke dua dilakukan adalah membuat naungan untuk tempat perkecambahan dan pembibitan. Naungan untuk tempat perkecambahan dibuat dari pelepah batang pohon kelapa sawit yang banyak di sekitar lokasi. Sementara naungan untuk tempat pembibitan dibuat dengan penutup para net. Hasil yang diperoleh adalah masyarakat lebih mengerti fungsi dari bangunan naungan yang dibuat. Salah satu

\section{Jurnal Deputi}


fungsi naungan itu adalah agar kecambah maupun bibit tidak terkena langsung sinar matahari.

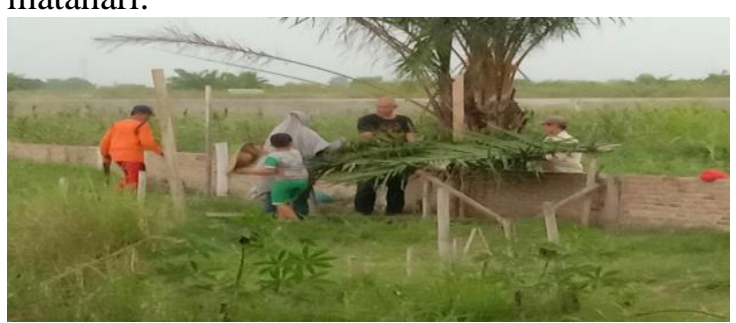

Gambar 3. Pembuatan Naungan Tempat perkecambahan dan Pembibitan

3. Perkecambahan Biji

Kegiatan yang ke tiga adalah mengecambahkan biji. Biji dari buah alpukat dan mangga terlebih dahulu harus dibersihkan dari sisa-sisa daging buah yang masih menempel di biji. Dan areal perkecambahan diberikan tanah bekas bakaran. Setelah itu biji didederkan dan disiram dengan pot rendaman kulit bawang merah dengan menggunakan spryer. Hasil yang diperoleh adalah masyarakat paham fungsi dari tanah bekas bakaran dan fungsi dari pot rendaman kulit bawang merah. Dan masyarakat juga diajarkan bagaimana cara membuat pot kulit bawang merah

4. Pengisian Polybag

Kegiatan ke empat adalah pengisian polybag dengan media tanam yang terdiri dari tanah, arang sekam dan pupuk kandang. Perbandingan media tanam 1:1:1. Hasil yang dicapai masyarakat memahami media tumbuh untuk pembibitan

5. Pemindahan Bibit ke Polybag

Kegiatan ke lima adalah memindahkan bibit ke polybag. Bibit yang dipindahkan adalah bibit yang sudah memiliki daun empat helai. Pemindahan bibit dilakukan dengan hati-hati agar tidak mengganggu perakaran bibit. Hasil yang diperoleh masyarakat paham bibit yang sudah bisa dipindahkan ke polybag

6. Penyusunan Polybag di Naungan Pembibitan

Kegiatan ke enam adalah menyusun polybag yang sudah berisi bibit tanaman ke naungan pembibitan. Fungsinya adalah agar bibit terlihat rapi dan masih ternaungi dari penyinaran matahari secara langsung

7. Pemeliharaan Bibit.

Kegiatan selanjutnya adalah pemeliharaan bibit tanaman mulai dari penyiraman, pemupukan, dan pengendalian hama dan penyakit. Hasilnya adalah masyarakat lebih memahami tahapan- tahapan yang dilakukan dalam pembibitan tanaman

\section{KESIMPULAN DAN SARAN}

Kesimpulan

Dari pelaksanaan kegiatan pengabdian masyarakat dapat disimpulkan :

1. Masyarakat mengetahui langkah -langkah dalam pembibitan tanaman yang berasal dari biji

2. Masyarakat mengetahui dan memahami bagaimana cara untuk menghasilkan bibit tanaman yang baik

\section{DAFTAR PUSTAKA}

Prastowo, N.H, James M. Roshetko, Gerhard E.S Maurung, Erry Nugraha, Joel M. Tukan, dan Frasiskus Harum. 2006. Tehnik Pembibitan dan Perbanyakan Vegetatif Tanaman Buah. World Agroforestry Centre. Bogor.

Wiraatmaja, I.W. 2017. Teknologi Budidaya Tanaman Buah-Buahan. Universitas Udayana. Denpasar.

Distan . 2019. Teknik Perbanyakan dari Biji atau Bibit Generatif. Dinas Tanaman Pangan dan Hortikultura Jawa Barat.

Purnomosidhi, P. Suparman , James M Roshetko dan Mulawarman. 2007. Perbanyakan dan Budidaya Tanaman Buah-buahan. World Agroforestry Centre \& Winrock International 